BACCHILEGA, Cristina: Fairy tales transformed? Twenty-first century adaptations and the politics of wonder. Detroit: Wayne State University Press, 20I3, 290 p.

\title{
Fairy tales transformed? Twenty-first-century adaptations and the politics of wonder
}

María Inés PALLEIRo

Consejo Nacional de Investigaciones Científicas y Técnicas de Argentina (CONICET) - Universidad de Buenos Aires, Argentina

This analysis by Cristina Bacchilega offers an updated and challenging approach to the study of fairy tales in contemporary societies. Cristina Bacchilega is professor of English at the University of Hawai'i at Manoa, where she teaches not only folklore and literature, but also cultural studies. She is the author of Postmodern fairy tales: gender and narrative strategies and Legendary Hawai'i and the Politics of Place: tradition, translation and tourism, and the co-editor with Danielle Roemer of Angela Carter and the Fairy Tale. Along with Donatella Izzo and Bryan Kamaoli Kuwada, she edited the Anglistica's special issue on "Sustaining Hawaiian Sovereignty". This paper, which discusses relocating and creolizing fairy tales, reflects her academic profile.

The author's aim is to explore the transformative possibilities of fairy tales as a wonder genre. By mapping connections on a global scale, Bacchilega analyzes the poetics and politics of fairy tales and their adaptations, in an intertwining of folklore, literature and cultural studies. Her proposal, as explained in this book, is to "provincialize" Euro-American fairy tales as a way to decolonize fairy-tale studies.

As a point of departure, the author examines the stakes of adapting fairy tales in the twenty-first century. She points out the relevance of considering the gender politics of fairy-tale adaptations in relation to other dynamics of power and she articulates her argumentation in different chapters. Her goal is to contest the hegemony of Euro-American fairy-tale magic by remapping the fairy-tale genre onto a worldly web.

The Preface raises the main questions of the approach: that is to say, how are fairy tales being adapted and what are the stakes of adapting fairy tales in the twenty-first century. Both the Introduction, "The Fairy-Tale Web" and the four chapters: I. "Activist Responses", 2."Double Exposures", 3. "Fairy-tale remix in film" and 4. "Resituating The Arabian Nights" give answers to these questions, summarized in the Epilogue "The Politics of Wonder". Thus, Bacchilega's journey begins in "the fairy-tale web", characterized as a set of intertextual and multimedia practices in a globalized culture. This point of departure leads her to consider "adaptations and relocations" of the fairy-tale, and to study its re-creations and remixes in filmic discourse. All these steps converge in situating The Arabian Nights in a new mapping of fairy-tale transformations. This journey through the fairy-tale web - with its relocations, adaptations, remixes and translations - allows her to identify a "poetics and politics of wonder" contained in contemporary fairy tales.

Bacchilega argues that fairy-tale adaptations circulating in the early twentyfirst century globalized culture are the result of the "geopolitics of inequality". She analyzes the global cultural practices reflected in "the fairy-tale web" as indexical 
signs of such geopolitics. Having reviewed the different adaptations of fairy tales in Euro-American contexts - from the Grimms and Perrault to Disney and Angela Carter - Bacchilega concludes that, in the globalized economy of the early twentyfirst century, tales are produced by means of intertextual practices. She affirms that in the fairy-tale web, links are hypertextual (that is to say, they do not refer back to one center). She identifies a transnational dynamics of creolizing the fairy tale in popular culture, and she sustains that such creolization rearticulates the fairy tale's world mapping from the perspective of local histories. By developing these arguments in different chapters, she explores the transformative possibilities of fairy tales as a wonder genre in a disenchanted world and she tries to give some "activist responses" to the above-mentioned initial questions.

In the first chapter, on "adaptation, remediation and relocation", Bacchilega considers that we are dealing with an adaptation when on reading, listening to or viewing a narrative text, we recognize its resemblance to another one in a different context. The changes from one text to another can include genre, medium, space or discourse. She provides several examples of this "art of transliteration" of the Perrault-Grimms-Disney normative canon towards indigenous resemantizations. One of them is Dan Taulapapa's adaptation of "Cinderella" (ATU 5IOA) as "Sinalela", located in Samoa. "Sinalela" is a short movie which recreates the canonic version of "Cinderella" in a créole version, mixed with vernacular traditions such as the "ula" dance. The name of the protagonist, Sinalela, combines "Cinderella" with the Samoan heroine Sina. Instead of dancing with the prince in a palace as Cinderella does, Sinalela goes to the poula, a Samoan night dance echoed in "ula". Such apparently irrelevant details give new créole meanings to these adaptations and relocations of "canonic" fairy tales. In an article entitled "Detail as the basic semantic unit in folk art", Mukarovsky emphasizes the role of such changing details in the resemantization of folk messages. ${ }^{\mathrm{I}}$ In this case, resemantization deals with relocation and adaptation of canonic versions of "Cinderella" in the American Indian context of Samoa. Bacchiega argues that adaptations such as Sinalela enact a politicized challenge to hegemonic tropes of genre, from the perspective of located knowledges.

She also regards the fairy-tale web as a methodological field which contributes to the critical decentering of the Euro-American literary fairy-tale tradition. Her argumentation tends to affirm that adaptations are indexical expressions of an emerging politics and poetics of wonder. According to Bacchilega, legitimating colonized knowledges and genres is part of the aforesaid "activist responses".

In the second chapter, the author deals with reading fairy-tale films as "double exposures" in contexts of "convergence cultures". She analyzes the representation of storybooks in films, and shows that filmic versions invoke the fairy-tale genre to "confront a social trauma". Bacchilega proposes thinking of the fairy-tale genre as a web whose hypertextual links participate in a convergence culture reflected in today's films. In an article regarding oral and

I. Mukarovsky, Jan (1977): "Detail as the Basic Semantic Unit in Folk Art". In J. Burbank and P. Steiner (eds.): The Word and Verbal Art: Selected Essays. New Haven: Yale University Press, p. I8O-204. 
virtual versions of "The vanishing hitchhiker", ${ }^{2}$ I also pointed out the similarity of folk narrative patterns with hypertextual structures. I compared the flexible structure of a hypertext, with its virtual links, with the compositional process of folk narrative matrices, the changing details of which result in alternative narrative itineraries. These flexible itineraries encourage our role of "hunters" of different routes across diverse contexts and channels of discourse in a sort of labyrinth, which recalls the text of Pan's Labyrinth analyzed by the author in this chapter. Bacchilega argues that, in the twenty-first century, we tell and receive stories in a convergence culture where the power of the media producers and consumers interacts in unpredictable ways. She examines the appropriation process of the authority of "classic fairy-tale authors" such as the Grimms and Perrault in filmic adaptations in which the tale is introduced as a book, as happens in the first scenes of Disney's Snow White. She also considers Disney's Enchanted and Dream Work's Shrek, which reaffirm romance and magic formulae as core ingredients of success in a capitalist world. Bacchilega also deals with other fairy tales that decommodify this magic by reading the genre for its horror and by refiguring the child as active reader and adapter. From this standpoint, she analyzes filmic versions such as Bluebeard, which "decommodify" the "gendered child". In this way, she compares Perrault's version of "Bluebeard" (ATU 3I2), edited in I697, with a filmic version by French director Catherine Breillat. Breillat activates a critical world of fantasy from a feminist perspective in her 2009 film La Barbe bleue. This film does not seek to renew the humans experience of wonder, but to replay the scene of "Bluebeard" which presents childhood as a traumatic site for girls in a patriarchal nuclear family. Bacchilega points out that the Bluebeard tale does not figure in North-American children's literature canon of fairy tales, but is referenced in popular culture as featuring a bloody chamber, a serial killer and other elements of horror and suspense rather than magic and wonder. The central point of Breillat's film - the fragility of the feminine condition - is made clear by means of one of the leading characters reading the tale out loud.

The cannibalistic ogre is placed in a gendered plot that teaches two sisters to be cunning to survive. Perrault is cited but not replicated in the storyworld of this film. In a "costume drama", one of the heroines survives when Bluebeard is decapitated, with the violence that the tale's narrative economy demands. In this analysis, Bacchilega argues that paying attention to how reading fairy tales works encourages taking responsibility for the social uses of fairy tales.

In the third chapter, the author analyzes the fairy tale remix "in different genres, histories and economies". She considers genre as a part of the relationship between texts and readers, and as a shared convention with a social force. She affirms that folklorists often define the fairy tale as a story world in which the supernatural is never questioned and the audience's suspension of disbelief is required. She examines how genres and worlds are mixed to achieve "different reality effects". To this end, she revisits big-budget films that mix fairy-tale elements such as Enchanted, Shrek and Pan's Labyrinth. She affirms that Shrek, produced by DreamWorks to contest Disney's corporate monopoly, starts by comically disrupting a classic fairy-tale frame with a stereotypical scenario as

2. Palleiro, María Inés (200o): "Death in the Ballroom. Orality and Hypertexts in Argentinean Folk Narrative”. Fabula. Zeitschrift für Erzählforschung / Journal of Folklore Studies no. 4I (3/4): 257-268. 
pre-text. The same thing happens in Enchanted, which also advertises Disney's "Princesses" franchises. Fragments of feminist ideas are trivialized in this film, in a remix within a dominant discourse of traditional gender roles. In Guillermo del Toro's Pan's Labyrinth, Bacchilega finds a contrast between fairy-tale and realistic generic worlds. She points out that some generic remixes of the fairy tale which may initially seem surprising are supported by formulaic homogeneity of genres. She deals as well with media texts that approach "Cinderella" as a tale centered on labor issues and sexual abuse by her father (ATU 5IOA). One of these texts is Dancehall Queen, a créolized and reframed "Cinderella", which rearticulates the folktale in the Jamaican setting of a dance competition.

Institutional forces inscribe filmic texts in a genre system by using the strategy of genre mixing. In this regard, she mentions the American Film Industry's definition of "fantasy" as "a genre where live-action characters inhabit imagined settings and/or experience situations that transcend the rules of the natural world", such as The Wizard of $\mathrm{Oz}$ or The Lord of the Rings. By considering this and other definitions, she points out the extent to which genres are mixed in the ongoing process of making genres. She also underlines that scholars are in competition with other knowledge communities. Fairy-tale film is a contested territory at the intersection of several genre systems across institutions, media, scholarly disciplines and cultural traditions. This has implications on how to approach the fairy-tale web geopolitically and methodologically.

The author seeks to approach filmic fairy-tale blending as an opportunity to focus on genre mixing and economies. In the analysis of Enchanted and Pan's Labyrinth, she underlines not only the merging of generic worlds but also the power relations that frame their production and reception. She considers social uses of the fairy-tale in these contemporary filmic fairy-tale remix, with the aim of contesting the implicit hierarchy of genre systems. From this standpoint, she asserts that there is much to learn from the genre's hybridization.

The last chapter focuses "resituating the Arabian Nights as an example of challenges of translation". Bacchilega considers translation to be adaptation and she points out that it always involves interpretation and transformative choices. From this standpoint, she pays attention to how translations and adaptations relocate the universalizing hierarchy of Western wonder genres. She affirms that adaptations of the Arabian Nights tend to construct the Orient as the other, connected with a politics and a culture of translation. She focuses on the strategies of "transporting" and "displacing" characters as symptoms of this geopolitical shift. Since translation always implies ethical and political choices, translations of the Arabian Nights show ideologies of representation. One of the examples of the $2 \mathrm{I}^{\text {st }}$-century Western adaptations of the Arabian Nights is Disney's Aladdin (I992), in which, as Bacchilega underlines, the genie wears the "obligatory" turban, colorful clothing, and accentuated eye makeup. This gives him an exotic and somewhat feminized look. In this way, the Thousand and One Nights has been transformed into a globalized visual production of an exotized magic. In media channels, the protagonists of the Arabian Nights such as Aladdin, Ali Baba and Sinbad have been reduced to cartoon heroes. These facts show the process of transforming the Arabian Nights into a "media text" of a visual globalized culture. In this way, Bacchilega explores the extent to which Western adaptations 
of the Arabian Nights contribute to a renewed politics of wonder that demands retranslation across media and different cultures.

The author also analyzes North-American adaptations in a comic-book series which makes explicit reference to current struggles in the Middle East. She deals with Bill Willingham's series of comics Fables, where the visual tropes from Arabian Nights such as Sinbad's turban are indexical signs of an interpretation of Oriental culture from Western popular culture. In this analysis, Bacchilega connects translations with processes of displacing characters, which involve fantasies of violence and usurpation. Such translations and adaptations show a political vision of reality whose structures promote the difference between the familiar European West and the strange Eastern Orient, identified with the "Other". In this text, as well as in numerous Hollywood images, this "Other" is represented by the barbaric Muslim world. Characters such as Ali Baba, then, become a metaphor of the Oriental danger. According to the author, this is a clear example of the geopolitics of inequality.

In the Epilogue, Bacchilega discusses "the politics of wonder" implicit in these contemporary adaptations and relocations of fairy tales. Her argumentation convinces the reader that such politics are contained in contemporary reworkings of fairy tales. She considers the meaning of "wonder", whose semantic field ranges from "marvel" to "thirst of knowledge" and "curiosity" as cognitive states of mind. From Angela Carter to Del Toro and the Grimms in their respective periods, fairy-tale adapters look to renew wonder in all its complexity. They also all call for active processes of storytelling and interpretation. Bacchilega inquires whether the politics of wonder plays a transformative role in today's adaptations of fairy tales. In her argumentation, she demonstrates that all adaptations are activist responses to potential transformations of the fairy tale, whose effects depend on our reception.

She also points out that in other contemporary literary traditions, such as in Oceania, direct engagement with the fairy tale is less common, since there seems to be a major concern about revitalizing homegrown wonder genres and indigenous epistemologies. This is the case in Hawai'i. While the translation of European fairy tales and the Arabian Nights into Hawaiian had an influence on nineteenth-century local literature, the fairy tale is not a genre of choice in Hawaiian adaptation projects today, possibly because the reframing of the Hawaiian mo'olelo as a fairy tale continues to have currency in popular imagination. A similar phenomenon can be observed in Argentina, whose oral tradition has no "fairies" only powerful witches and personified animals, connected with indigenous traditions, which have not entered the domain of global media culture.

The purpose of the author is to highlight the significance of epistemologies based on multimedia fairy-tale traditions and to think about the relationship of fairy tales with other cultures' wonder genres. She also states that it is worth undoing the Grimms' authority through storytelling. Using translations and ethnographies, comparative literature can study both oral and written literatures from all over the world, and show how literary and folkloric texts are embedded in a variety of local social contexts. Relocating knowledge also means recognizing visual culture as a non-linguistic semiotic system that impacts the storytelling of oral and literate societies. Bacchilega concludes that it is worth learning from 
the emergent poetics of those who are rewriting the fairy tales from located and decolonizing perspectives. She also underlines that fairy-tale studies must be transdisciplinary. Thus, she proposes a new cartography of knowledge and genres, in a transnational approach to folktales and fairy tales that recognizes local perception of history.

The book includes iconic texts as examples of the author's affirmations. Recording folk narrative is not, however, the aim of this work; rather it is to study contemporary transformations of fairy tales. Bacchilega provides such wonderful illustrations as the filmic re-creation of "Sinalela" contextualized in an American Indian environment and the Arabian Nights in comics, used with permission of Bill Willingham \& DC Comics. The book also contains notes for each chapter, a very useful index of names and authors, a list of the filmography and a final bibliography.

With clear and engaging prose, the author offers both academic scholars and readers interested in fairy tales a wise analysis of the changes in fairy-tale patterns in globalized societies of the early $2 \mathrm{I}^{\text {st }}$ century, connected with the poetics and politics of wonder. 